\title{
CROATIAN AND SERBIAN WAR CRIMES, THE INTERNATIONAL CRIMINAL TRIBUNAL FOR THE FORMER YUGOSLAVIA, AND THE JUDICIAL SYSTEMS OF SERBIA AND CROATIA
}

\begin{abstract}
The war in former Yugoslavia (1991-1995) was marked by war crimes which still affect Serbian-Croatian political relations. The International Criminal Tribunal for the former Yugoslavia (ICTY), which operated between 1993-2017, was supposed to pass fair verdicts on those responsible for war crimes, but its verdicts have been surrounded by controversy in Post-Yugoslav states. The article analyzes Serbian and Croatian war crimes in Croatian territory between 1991-1995 as well as the verdicts passed by the ICTY against the most prominent war criminals. The actions taken by the Serbian and Croatian judicial systems are also discussed. The analysis presented in the article indicates that the verdicts delivered by the ICTY were selective and difficult to accept for both sides of the conflict. Unfortunately, Serbo-Croatian cooperation on war crimes has been developing for only a few years and has not produced the expected results. For these reasons, war crimes and war criminals still have a negative influence on political and social relations between the Republic of Croatia and the Republic of Serbia.
\end{abstract}

Key words: Serbia; Croatia; International Criminal Tribunal for the former Yugoslavia; war crimes; genocide
WIKTOR HEBDA Uniwersytet Jagielloński w Krakowie E-mail: wiktor.hebda@uj.edu.pl http://orcid.org/0000-0002-3279-7400

CITATION: Hebda, W. (2020). Croatian and Serbian war crimes, the International Criminal Tribunal for the former Yugoslavia, and the judicial systems of Serbia and Croatia. Sprawy Narodowościowe: Seria nowa, 2020(52), Article 2050. https://doi.org/10.11649/sn.2050

This work was supported by the author's own resources. No competing interests have been declared.

This is an Open Access article distributed under the terms of the Creative Commons Attribution 3.0 PL License (creativecommons.org/licenses/by/3.0/pl/), which permits redistribution, commercial and non-commercial, provided that the article is properly cited. (C) The Author(s) 2020

Publisher: Institute of Slavic Studies, Polish Academy of Sciences

Publishing History: Received 2020-07-04; Accepted 2020-12-13; Published 2020-12-23 


\section{SERBSKIE I CHORWACKIE ZBRODNIE WOJENNE, MIĘDZYNARODOWY TRYBUNAL KARNY DLA BYŁEJ JUGOSLAWII ORAZ SERBSKI I CHORWACKI WYMIAR SPRAWIEDLIWOŚCI}

\section{Streszczenie}

Kwestia zbrodni wojennych i obiektywnego osądzenia zbrodniarzy wojennych jest wysoce problematyczna. Bezspornie wojna w byłej Jugosławii z lat 1991-1995 była tragiczna w skutkach i naznaczona wydarzeniami, którym można nadać miano zbrodni wojennych. Międzynarodowy Trybunał Karny dla Byłej Jugosławii (MTKJ) funkcjonujący w latach 1993-2017 miał w założeniu sprawiedliwie osądzić osoby odpowiedzialne za zbrodnie wojenne. Niemniej jego działalność (orzeczone kary) wzbudza pewne kontrowersje, a co za tym idzie może być i jest krytycznie oceniana. W artykule przedstawiono syntetyczną analizę serbskich oraz chorwackich zbrodni wojennych mających miejsce na terytorium Chorwacji w latach 1991-1995. Następnie odniesiono się do kar orzeczonych przez MTKJ wobec najważniejszych zbrodniarzy wojennych. W tym też aspekcie zwrócono uwagę na aktywność serbskiego i chorwackiego wymiaru sprawiedliwości. Analiza zawarta w artykule potwierdza tezę że wydawane wyroki przez MTKJ odznaczały się selektywnością, dlatego też w niektórych przypadkach były one trudne do zaakceptowania przez obie strony konfliktu. Niestety serbsko-chorwacka współpraca w zakresie zbrodni wojennych rozwija się dopiero od kilku lat i nie przyniosła oczekiwanych rezultatów. Z tych też powodów zbrodnie wojenne i zbrodniarze wojenni nadal mają negatywny wpływ na stosunki polityczne i społeczne między Republiką Chorwacji a Republiką Serbii.

Wyrazy kluczowe: Serbia; Chorwacja; Międzynarodowy Trybunał Karny dla Byłej Jugosławii (MTKJ); zbrodnie wojenne; ludobójstwo

\section{INTRODUCTION}

W ar crimes are still a problematic aspect of international law and international relations as well. There are a whole range of theories and interpretations explaining the concept of war crime, crime against humanity or genocide and it should be emphasized that these concepts are ambiguous (Akhavan, 2008, pp. 23-30; Dörmann, 2003, pp. 343-403; Frulli, 2001, pp. 332-346; Hathaway et al., 2019, pp. 54113; Iwanek, 2015, pp. 163-170, 257-261; MacFarland \& Hamer, 2016, pp. 76-83; Maier-Katkin et al., 2009, pp. 231-247; Makino, 2001, pp. 50-59; Marchuk, 2014, pp. 69-114; Straus, 2001, pp. 360-370). War crimes from the years 1991-1995 that occurred in the Socialist Federal Republic of Yugoslavia (SFRY) are a key factor affecting the quality of Serbian-Croatian political relations after the year 2000. This issue also remains fraught because both nations and their political elites have a disparate view of the conflict that resulted in the breakup of the Yugoslav federation. The Croats call it domovinski rat (Homeland War, Croatian War of Independence), which was a fight for independence mostly against Croatian Serbs. However, for the Serbs it was a civil war in Yugoslavia caused by national independence trends in Croatia, Slovenia, Bosnia and Herzegovina (Hayden, 2011, p. 318; Zambelli, 2010, pp. 1675-1680). Croatian politicians were aiming to strengthen the sovereignty of their state while Serbian ones wanted to defend the Yugoslav federation. Consequently, both sides initiated and contributed to the intensification of the dispute, which finally led to armed conflict. The war in SFRY was the most complex (its background was both national and religious) and bloody (over 100,000 victims) 
military confrontation in European history since 1945. Numerous cases of war crimes were reported involving both Serbian and Croatian soldiers, paramilitary troops and even civilians. As a result - even with an ongoing war - the United Nations established the International Criminal Tribunal for the former Yugoslavia (ICTY), whose main aim was to prosecute the perpetrators of the war crimes. As might be expected, the post-war cooperation with the state authorities (parties to the conflict) was limited and therefore bringing war criminals to justice has always been challenging (Hoare, 2003, pp. 543-562; Kerr, 2007, pp. 375-182). Political changes in Serbia and Croatia have affected attitudes towards the Yugoslav war and those responsible for the conflict. As time passed, the most prominent individuals accused of committing war crimes were arrested, but the issue still remains an obstacle to improving Serbian-Croatian political relations.

This article aims to define the scale of Serbian and Croatian war crimes from 19911995 and the importance of the International Criminal Tribunal for the former Yugoslavia in Serbian-Croatian dispute.

\section{WAR CRIMES IN THE SERBIAN-CROATIAN CONFLICT IN CROATIA BETWEEN 1991 AND 1995}

All parties in the conflict in the former Yugoslavia between 1991 and 1995 committed war crimes. Taking into consideration Serbian crimes committed against the Croats, special attention should be drawn to the events in Slavonia and Krajina - Croatian territories then controlled by the Republic of Serbian Krajina (Republika Srpska Krajina, RSK). The most serious of war crimes occurred in Vukovar and the surrounding areas in Slavonia. At the end of August 1991, the Yugoslav People's Army laid a three-month siege to the city of Vukovar during which hundreds of civilians were killed and a significant part of the city was destroyed. On the 20 November 1991, Serbian military troops captured around 250 people and then shot them on the outskirts of Vukovar (Ovčara). Meanwhile, in Slavonia a paramilitary unit called Arkan's Tigers was particularly active. From October 1991 to February 1992, its members murdered more than a hundred Croatian civilians in the small Danubian village of Erdut, and several more in Trpanji. Serbian paramilitary group the White Eagles was also charged with committing war crimes. In November and December 1991 its fighters brutally murdered 75 people living in the Voćin area. Some tragic events also took place on the Croatian-Bosnian border in Hrvatska Dubica region. On 21 October 1991, members of the so-called Martić Police executed 56 civilians (mostly Croats) in Krečane, next to Baćin and 54 more people were murdered in the following days. Other crimes of Serbian soldiers and paramilitary units were also reported; for example, on 21 October 1991 in Lovas, Croatian civilians were first forced to step into a minefield and were then shelled so that 21 people were killed. On 4 May 1992 near Beli Manastir, five residents of Grabovac were murdered. In the region of Krajina, Lika and Dalmatia a few cases of war crimes were reported, the most serious of which were near Plitvice Lakes, Zadar and Knin. On 28 October 1991 in Lipovača (a village in the region of Rakovica) seven Croatian civilians were killed, while on 12 November 29 residents were executed in Saborsko, then the whole place was destroyed. In December the same year near Plitvice Lakes, 10 people were murdered (the village of Vojkovići). At the same time, in Korenica a prison camp was set up that became a place of torture, brutal beatings and sexual assaults. Troops of the Yugoslav People's Army, assisted by Serbian paramilitary groups, 
also committed serious crimes in the region of Zadar. On 18 November 1991 in Škabrnja, 38 people were murdered by Serbian combatants while subsequent executions took the lives of 26 more prisoners of war (International Criminal Tribunal for the former Yugoslavia [ICTY], n.d.-h). The following day Serb forces attacked and took the village of Nadin, where they murdered seven civilians. Moreover, in December 1991 one of the units of the so-called Martić Police murdered ten residents of the village of Bruška (ICTY, n.d.-d).

On the issue of war crimes, one should not forget the Serbian siege of Dubrovnik. As a result of the shelling between 1 October and 7 December 1991, 43 residents were killed, many were wounded, while the historic UNESCO World Heritage Old Town was severely damaged (ICTY, n.d.-e). Zagreb was also a target of heavy rocket shelling. On 2 and 3 May 1995, an attack caused the death of six civilians, 160 people were wounded, and some public buildings were partially damaged, including The National Theatre and the hospital (ICTY, n.d.-i). It should also be mentioned that in Knin, the capital of the RSK, a jail was established and about 120 Croatian prisoners were starved and tortured there (ICTY, n.d.-g). All things considered, it seems to be evident that the number of war crimes against the Croats in the second half of 1991 and the beginning of 1992 is highly significant.

The following years witnessed numerous war crimes committed by Croatian military forces on the territory of the self-proclaimed RSK. Between 9 and 11 September 1993, near Gospić, the Croats conducted a military operation called Medački džep, as a result of which eleven Serbian villages were razed to the ground. Officially, Croatian soldiers murdered 29 residents of controlled villages, nevertheless it is presumed that there were more than 100 victims (the bodies were successfully hidden or destroyed) (ICTY, n.d.-f). What's more there were numerous acts of brutality against Serbian soldiers and civilians; for example, a woman was publicly burned alive, bodies were pulled behind cars, extremely cruel acts of torture were inflicted, etc. At this point, it is important to return to the events of January 1993. According to Serbian sources, the Croatian offensive during the Maslenica operation (near Zadar) resulted in the death of 165 residents from Smoković, Kašić, Islam Grčki and other villages (Radio Television of Republika Srpska, 2011). Most of the buildings were subsequently destroyed or burnt (Bieber, 2003, p. 43). Many examples of war crimes occurred during the Croatian Bljesak and Oluja military operations, the former of which was an offensive of combined police and military forces conducted from 1 to 3 May 1995 in the area of Okučani (Mirkovic, 2000, p. 369). As a result, about 12,000 Croatian Serbs were either displaced or forced to leave. Hundreds of soldiers and civilians were killed (the exact number differs depending on the information source). From a military perspective, operation Oluja, which occurred between 4 and 7 August 1995, was much larger. One can grasp the scale of this operation when confronted with the fact that Croatian forces covered a 630-kilometer-long battlefront. The Croats' main aim was to regain control over the RSK. The mission was accomplished at the cost of the lives of Serbian civilians who in some cases fell victim to war crimes (Burg \& Shoup, 1999, p. 414). According to the statistics released by the International Criminal Tribunal for the former Yugoslavia, more than 300 people were murdered, mostly near Knin and Gračac; for example, in the town of Gračac 33 Serbian civilians were killed. In the municipalities of Donji Lapac, Kistanje, Biskupija, and Ervenik a total of 50 people were murdered. In the capital of the RSK and surrounding villages 14 more bodies were found, but the number of victims in Knin has never been determined. In-depth research carried out in 2001 by the Croatian department of the International Helsinki Federation for 
Human Rights confirmed the murder of 677 Serbian civilians during operation Oluja; however, according to data from 2014 that was provided by the Serbian institution Veritas, 1,078 civilians were murdered (out of 1,719 killed on the Serbian side) (Dokumentaciono informacioni centar Veritas, 2014). What sparked numerous controversies was the question of who was responsible for the mass murder in Dvor by the river Una. On 8 August 1995, about ten disabled people were murdered in the local school. The victims were mostly of Serbian origin (according to different sources 7 to 12 people were killed). Nobody prevented these tragic events from happening despite the presence of Danish soldiers stationed on behalf of the UN. Although for many years Croatian authorities claimed that these barbarous crimes had been committed by the Serbs, the evidence points to members of the Croatian armed forces (Rašović, 2016).

The aftermath of the Croatian offensive involved forced displacement and massive migration of the Serbian community which, depending on the information source, affected about 200,000 to 250,000 people. Furthermore, it should be noted that in the years 1992-1997 the Croatian concentration camp in Split remained active. About one thousand people mostly of Serbian origin were tortured there and 25 prisoners were killed or died from injuries (Komitet za prikupljanje podataka o izvrešenim zločinima protiv čovečnosti i međunarodnog prava, 1998). Nowadays the scale of Croatian crimes seems almost impossible to determine, but multiple and various sources prove that such crimes most definitely occurred.

For many years, both sides of the conflict have been accusing each other of genocide and the war crimes mentioned above. According to various pieces of research, the Serbian-Croatian conflict led to the death of 20,000 to 22,000 people in the territory of today's Croatia between 1991 and 1995 (Bjelajac \& Žunec, n.d., p. 49). The exact number of Croatian victims fluctuates from 12,000 to 16,000 . Such a discrepancy is caused by the fact that a few thousand people were considered missing. In Serbia's case, the death toll was 6,000-8,000, most of whom were civilians (Žunec, 1998, p. 132). The exact number is yet again difficult to define and oscillates between 7,000 and 10,000 . Also horrifying is the number of people injured, both physically and mentally. Thousands of Serbs and Croats suffered physical injuries (resulting from gunshot wounds, torture or the wide-scale usage of anti-personnel mines). In fact, Balkan states are still struggling to neutralize explosives in minefields which cover the vast area along the front lines (the border of the then RSK) (Croatian Mine Action Centre, n.d.).

Another tragic outcome of the Serbian-Croatian conflict was the forced displacement or mass migration of civilians. Bearing in mind the fact that the Croatian operation Oluja resulted in a mass exodus of Serbs from Croatia, it is fair to assume that the Serbian minority was particularly affected (Radoš, 2011, p. 293). To sum up, between 1991 and 1995 about 300,000-350,000 Serbs left Croatia, most of whom never returned to their homes (Human Rights Watch, 2003, p. 3). The issue of missing people and looting remains one of the major obstacles in maintaining post-war political relations. Official numbers indicate that 8,000 people remain missing (Nikolic, 2015). The Serbian state also demand from the Croats actual damages for the loss or destruction of their properties. They raise the issue of damaged or completely destroyed buildings in places which were occupied by the Serbian minority. In fact, the material damage caused by the conflict was rather significant with a total cost of 27 billion dollars (Žunec, 1998, p. 133). Consequently, areas which were poor even before the war (for instance central Croatia) were badly hit by an economic crisis after the war. 
The International Criminal Tribunal for the former Yugoslavia (with its headquarters in the Hague) was established by Resolution 827 of the United Nations Security Council, passed on 25 May 1993. The tribunal had been active for almost a quarter-century by 31 December 2017. Its aim was to prosecute those responsible of grave violations of international humanitarian law committed in the territory of the former Yugoslavia since 1991 (International Tribunal for the Prosecution of Persons Responsible for Serious Violations of International Humanitarian Law, 2009). The second article of the ICTY's statute lists all the acts considered to be grave breaches of the Geneva Conventions of 1949, e.g. willful killing, torturing or inhumane treatment, including biological experiments, willfully causing great suffering or serious injury to body or health, extensive destruction and appropriation of property not justified by military necessity and carried out unlawfully and wantonly. Article 3 of the ICTY Statute relates to violations of the laws or customs of war. Such violations include wanton destruction of cities, towns or villages, or devastation not justified by military necessity; attack or bombardment by whatever means of undefended towns, villages, dwellings, or buildings as well as plunder of public or private property. Article 4 defines genocide as an act committed with the intent to destroy, in whole or in part, a national, ethnical, racial or religious group. This part of the statute lists the features of genocide: killing members of a specific group, causing serious bodily or mental harm to members of a group, deliberately inflicting on a group conditions of life calculated to bring about its physical destruction in whole or in part, imposing measures intended to prevent births within a group as well as forcibly transferring children of a group to another group. The article also states clearly that not only genocide is punishable, but also conspiracy to commit genocide, direct and public incitement to commit genocide, attempt to commit genocide and complicity in genocide. This article also defines crimes against humanity, such as murder, extermination, enslavement, deportation, imprisonment, torture, rape, persecutions on political, racial and religious grounds and other inhuman acts.

In the years 1997-2004 the ICTY issued indictments against 161 people, but in some cases judicial proceedings were closed only in November 2017 (ICTY, 2019). It must be noted that the vast majority of the indicted identify themselves as Serbs (94 people). Among that group one can distinguish five representatives of Croatian Serbs who played key roles in the RSK: Goran Hadžić, Milan Babić, Milan Martić, Slavko Dokmanović and Mile Mrkšić. Furthermore, indictments were also issued against Serbs from the Republic of Serbia and from Bosnia and Herzegovina, the most serious of which involved Slobodan Milošević, Radovan Karadžić, Ratko Mladić, Momčilo Krajišnik, Radislav Krstić, Momir Talić, Zdravko Tolimir and Goran Jelisić. The most important person among the indicted was undoubtedly Slobodan Milošević - the president of the Republic of Serbia and then of the Federal Republic of Yugoslavia. This politician was arrested in Belgrade in April 2001, then in June he was transferred to the Hague. The ICTY charged him with 66 counts, including violation of the Geneva Conventions during the conflict in Croatia. Among other crimes, Milošević was held responsible for extermination of hundreds of civilians in several places in Croatia, for instance in Vukovar and Dubrovnik; imprisonment of thousands of Croats and holding them in inhuman conditions; mass deportations of Croatian civilians (170,000 people), for instance from Vukovar; willful destruction of houses and other private and public buildings of historic, cultural and religious value (ICTY, n.d.-r). The trial began in February 2002, but it was brought to a halt in March 2006 due to the defen- 
dant's death. According to an official statement, Slobodan Milošević died of a heart attack in his prison cell on 11 March 2006, but the circumstances surrounding his death raised a lot of controversies (Telegraf, 2016). After the year 2000, Serbian-Croatian political dialogue paid a lot of attention to Radovan Karadžić and Ratko Mladić. The former remained in hiding until July 2008, while the latter did the same until May 2011. Both of them were captured in the Republic of Serbia - a fact that gave the Serbs a lot of adverse publicity in the international arena. In March 2016, Radovan Karadžić was found guilty of genocide and war crimes and was sentenced to 40 years' imprisonment (ICTY, n.d.-o). The last verdict was announced on 22 November 2017, when Ratko Mladić was sentenced to life imprisonment (ICTY, n.d.-p). Bearing in mind the acquittal of Ante Gotovina, such severe punishments for Karadžić and Mladić have raised some doubts (Hebda, 2018, pp. 243-256).

When it comes to Serbian-Croatian political relations, the Croats find it imperative to indict Croatian Serbs who are responsible for war crimes committed in the territory of the Republic of Croatia between 1991 and 1995. One of them was Goran Hadžić - the leader of the self-proclaimed Serbian Autonomous Oblast of Eastern Slavonia, Baranja and Western Syrmia (1991-1992), the then president of the RSK (1992-1994) and the leader of the coordination committee of Eastern Slavonia, Baranja and Western Syrmia (19961998). The indictment act included, for example, murdering around 250 Croats (hospital patients) in Ovčara when Serbian military troops took control over Vukovar (20 November 1991), and murdering 35 Vukovar residents and unlawful holding of Croats in inhuman conditions (ICTY, n.d.-b). Hadžić managed to remain in hiding for several years but was finally arrested in Serbia in July 2011 (as the last person indicted by the ICTY) and transferred to prison in the Hague. In April 2015 he was provisionally released from prison due to his ill-health (brain cancer) and he died in July 2016. Another captured perpetrator, Milan Babić - the president of the RSK (1991-1992) and its prime minister (1995) - faced charges of, for example, persecution of non-Serbs in Krajina. In June 2004 he was sentenced to 13 years' imprisonment (he committed suicide in March 2006) (ICTY, n.d.-k). However, many more charges were pressed against Milan Martić, who between 1991 and 1995 served various functions in the RSK (the president, the minister of national defense, the minister of foreign affairs). The ICTY accused him of, for example, creating and managing the so-called Martić Police, which was responsible for multiple murders of Croats, extermination and forced displacement of non-Serbian communities from areas in the RSK, and planning and ordering the rocket shelling of Zagreb in May 1995. In June 2007 Milan Martić was sentenced to 35 years' imprisonment for war crimes and crimes against humanity. Since 2009 he has been serving his sentence in a penitentiary in Tartu, Estonia (ICTY, n.d.-I). In the case of Slavko Dokmanović - the mayor of Vukovar in 1990-1991 who was charged with complicity in crimes (Ovčara, Grabovo) - judicial proceedings before the ICTY were not successful (ICTY, n.d.-q). Slavko Dokmanović was captured by the Polish GROM military unit in June 1997, but a year later he committed suicide in his prison cell in the Hague. The last of the aforementioned Croatian Serbs was Mile Mrkšić. He was the colonel of the Yugoslav People's Army and after taking Vukovar he was promoted to general and commander in chief of the 8th Operational Group in the region of Kordun in Croatia. Mrkšić was later indicted for murders, tortures and the inhumane treatment of prisoners. In 2007 he was sentenced to 20 years' imprisonment. In 2012 he started serving his term in Portugal, where he died in August 2015 (ICTY, n.d.-n). Here, the case of Miodrag Jokić should also be mentioned as this Serb vice admiral and Yugoslav Navy commander was responsible for the shelling of Dubrovnik in December 
1991. In 2003 Miodrag Jokić was sentenced to 7 years' imprisonment, but in 2008 he received early release from prison (ICTY, n.d.-m). Between 1991 and 1992 in the region of Western Slavonia, multiple crimes were committed by the Arkan's Tigers paramilitary unit. In 1997 its commander Željko (Arkan) Ražnatović was officially indicted by the ICTY for crimes against humanity, but he was never sent to prison. His case was soon closed; in January 2000 he was shot and later died in Belgrade (ICTY, n.d.-t). Another perpetrator whose activity provoked much controversy in Croatia for many years is Vojislav Šešelj, who was also indicted by the ICTY. His counts included complicity in murders, torture, persecution on political, racial and religious grounds, and hate speech. This leader of the Serbian Radical Party was imprisoned in the Hague in 2003, but in November 2014 he was provisionally released from prison due to ill-health (ICTY, n.d.-s). He soon returned to being politically active in the Republic of Serbia - mostly by promoting hate speech against Croatia. At the end of March 2016 he was acquitted on all counts by the ICTY - an outcome which resulted in official protests by Croatian politicians (Tanjug, 2016).

Judicial proceedings before the ICTY also involved Croats who were responsible for war crimes in the years 1991-1995. For the sake of Serbian-Croatian political relations it was imperative to indict Croats who had committed crimes on Serbs from the RSK. The Serbs called for fair sentences for those involved in Croatian military operations such as Medački džep or Oluja. In this matter the key perpetrator was Ante Gotovina - a Croatian general, commander in the Oluja operation, later in charge of the Croatian Army (19962000). The ICTY issued an indictment against Gotovina in 2001, but in the following years he remained in hiding. He was arrested in December 2005 in Spain and then transferred to the Hague. Ante Gotovina faced multiple charges including war crimes and crimes against humanity, for example issuing an order to kill at least 150 Serbs from Krajina and the forced displacement of around 200,000 more. In April 2011 the Hague Tribunal sentenced this Croatian general to 24 years' imprisonment (ICTY, n.d.-c). The verdict was criticized not only by Croatian politicians, but also by the Croatian public, for whom Ante Gotovina was a national hero (Pavlaković, 2010, pp. 1718-1724). It should be mentioned that an opinion poll carried out right after the ICTY's sentence was announced showed that $95.4 \%$ of respondents found the verdict unfair (Butković, 2011). In November 2012, after filing an appeal against the ICTY's verdict, Ante Gotovina was acquitted on all counts (Hebda, 2018, p. 252). In this way the man whom the Serbs consider a war criminal still enjoys his freedom (Subotić, 2014, pp. 172-173). In the Oluja case, other Croats were also indicted. General Ivan Čermak was the vice president of the executive board of the Croatian Democratic Union, an advisor to Franjo Tuđman (the president of the Republic of Croatia), and to the minister of national defense in the years 1991-1993. Between August and November 1995 he served as the commander of the Knin corps, therefore he was directly involved in the Oluja operation. As a result, he was indicted by the ICTY on counts of war crimes. Ivan Čermak was put in Hague prison in 2004, but he was never found guilty of any complicity in any crimes and in April 2011 he was consequently acquitted on all counts. The next defendant was general Mladen Markač, who in 1994 was put in charge of special units of the Croatian police. During the Oluja operation he controlled several police units and therefore was accused of the crimes committed by these troops. Similarly to Ivan Čermak, he was transferred to ICTY in 2004 and by the virtue of the verdict of April 2011 he was sentenced to 18 years' imprisonment. Several months later, following an appeal lodged with Ante Gotovina, he was acquitted on all counts and released from prison (ICTY, n.d.-C). In this way, on the grounds of the verdicts passed by 
ICTY, the highest-ranked commanders involved in the Oluja military operation were never held responsible for the war crimes that had undoubtedly taken place.

However, the ICTY dealt with one more criminal case directly connected to military activities in Croatia. The case concerned the Medački džep military operation of September 1993. Two members of the Croatian army were charged with committing war crimes: Janko Bobetko and Mirko Norac (Peskin \& Boduszyński, 2003, pp. 1126-1135). As chief of general staff of the Croatian Army between 1992 and 1995, Janko Bobetko coordinated military activities during Medački džep. In 2002 the ICTY indicted him for, among others, persecution on political, racial and religious grounds, compliance in the murder of around one hundred Serbian civilians, torturing prisoners of war and devastation of public and private property. Janko Bobetko died in April 2003, thus closing criminal procedures against him (ICTY, n.d.-j). The second accused was general Mirko Norac - the commander of the 9th Guards Motorized Brigade of the Croatian army in 1993, which was directly involved in the Medački džep operation. The indictment included numerous war crimes such as the murder of Serbian civilians, cruelty and inhuman treatment of prisoners of war and terrorizing civilians. In 2004 he was transferred to the Hague from a Croatian prison (in 2003 a Croatian court in Rijeka sentenced him to 12 years' imprisonment). However, in September 2005 the ICTY moved his case back to the Croatian judiciary (ICTY, n.d.-a). Therefore, by virtue of the verdict given by the court in Zagreb in 2008, Mirko Norac was sentenced to seven years' imprisonment. After serving three years of his term (10 years after his arrest in 2001), he was provisionally released from the penitentiary. It must be emphasized that Franjo Tuđman - a Croatian political leader in the 1990s - was never charged with war crimes by ICTY, also due to his death in 1999 (Hebda, 2018, p. 253).

To explain these war crimes, it is essential for the Croatian and Serbian judicial systems to work together. Not until the beginning of the twenty-first century did the political climate become favourable to initiating such cooperation. Until 2005, the partnership was based on two documents: the Memorandum of Cooperation between the Federal Republic of Yugoslavia and the Republic of Croatia in terms of legal assistance in civil and criminal matters (signed in 1997) and the European Convention on Mutual Assistance in Criminal Matters. In February 2005 the Serbian and Croatian public prosecutor's offices signed a Memorandum of cooperation in which they agreed to act against any forms of serious crime, including war crimes. A year later, in October 2006, they signed a contract on cooperation in the prosecution of perpetrators of war crimes, crimes against humanity, and genocide. The greatest benefit of the agreement was the possibility to exchange legal documents describing proceedings instituted against war criminals. By the end of 2015, the prosecutors' offices of both countries had managed to exchange almost one hundred criminal files, which in some cases turned out to be essential during trials. This was how the Serbian Public Prosecutor's Office for War Crimes received from the Croatian Attorney's General Office information about 36 criminal cases against 63 people, on the grounds of which 20 were sentenced (Ten years of war crimes prosecutions in Serbia, 2014, pp. 25-26). Unfortunately, the success of this cooperation was seriously threatened in 2011, when the Croatian parliament passed a bill on the invalidity of some judicial acts of the former Yugoslav People's Army, the Socialist Federal Republic of Yugoslavia, and the Republic of Serbia (Zakon o ništetnosti određenih pravnih akata pravosudnih tijela bivše JNA, SFRJ i Republike Srbije, 2011). Article 3 of this bill states that the Croatian judicial authorities will not act upon any motion of Serbian judicial authorities in matters 
relating to legal assistance in criminal cases if such a motion stands in contradiction to the legal order of the Republic of Croatia and harms its sovereignty and security. What is more, when the bill entered into force, it invalidated all legal acts issued by the judicial authorities of the Yugoslav People's Army, the Socialist Federal Republic of Yugoslavia, and the Republic of Serbia relating to the war in Croatia in which a Croatian citizen was suspected, indicted or sentenced for crimes violating norms of international humanitarian law. Consequently, some criminal cases, e.g. against Tihomir Purda, Vesna Bosanac, Vladimir Šeks, which were taken over by the Serbian Public Prosecutor's Office for War Crimes, were non-binding in the eyes of Croatian law. Nevertheless, the Serbian public prosecutor's office continued its work in that matter. After Croatian parliamentary elections in December 2011, Milanović's newly formed government expressed its skepticism towards this controversial bill, while the president, Josipović, filed a motion to the Constitutional Court requesting an inquiry into the constitutionality of the bill. The status of this presidential motion remained pending for over three years until, finally, in February 2015, Josipović decided to withdraw the motion (Dokumentaciono informacioni centar Veritas, 2015). It needs to be highlighted that despite political and legal obstacles, the cooperation of the Serbian-Croatian judiciaries resulted in the solving of many criminal cases related to, for instance, crimes in Vukovar (Ovčara), Split (the Lora camp) or operation Oluja (National strategy for the prosecution of war crimes for the period 2016-2020, 2016). According to the information provided by the Attorney General's Office of the Republic of Croatia, on 30 June 2017 Croatian courts were handling legal proceedings against 3,556 people suspected of war crimes. In 608 cases the courts pronounced guilty verdicts with various terms of imprisonment (Državno odvjetništvo Republike Hrvatske, 2017). It should be mentioned though that most of the suspects identified themselves as of Serbian origin. Out of over 3,500 suspects, only 119 were members of the Croatian military forces and only 44 were found guilty (Državno odvjetništvo Republike Hrvatske, 2014). So far, the Serbian Public Attorney's Office for War Crimes has filed 66 criminal cases, 21 of which concern those suspected of war crimes committed in the territory of the Republic of Croatia (Tužilaštvo za ratne zločine [TZRZ], n.d.-a). The largest case, Ovčara (Vujović and others), came to a close after almost 14 years on 24 November 2017). 9 of the 18 indicted suspects were sentenced to a total of 121 years' imprisonment (TZRZ, n.d.-c). Another important lawsuit concerns the Lovas case (Devetak Ljuban and others). In 2012 the Court of First Instance sentenced 14 people to a total of 128 years' imprisonment (TZRZ, n.d.-b). Unfortunately, for the last couple of years there has been a visible slowdown in Serbian-Croatian reconciliation. Consequently, cooperation in the prosecution of war criminals is limited.

\section{CONCLUSION}

The issue of crimes and war criminals has influenced Serbian-Croatian political relations almost since the end of the conflict in 1995. However, mutual interest in this matter increased after the year 2000, and only then was it possible to talk about common initiatives whose aim was to shed some light on these problematic topics. The International Criminal Tribunal for the former Yugoslavia in the Hague played a key role in this matter. Its main aim was to judge the most prominent people suspected of war crimes and cri- 
mes against humanity. Any evaluation of its activity remains a matter of dispute, while the verdicts it delivered are most definitely controversial, especially in the states directly related to these issues (Akrivoulis, 2017, pp. 371-373; Milojevich, 2019, pp. 4-7; Steflja, 2010, pp. 239-243). The Serbian and Croatian jurisdiction is handling lawsuits against all remaining perpetrators involved in war crimes in the territory of Croatia and Serbia in 1991-1995. In this aspect, one can find not only some positive accomplishments (e.g. cooperation between public prosecutors' offices), but also plenty of mutual objections to legislation or criminal proceedings. Unfortunately, Serbian-Croatian political relations are strongly correlated with social feelings towards the events that occurred between 1991 and 1995. Some parts of society still respect those responsible for crimes, justifying their evil actions in terms of defending the interests of the nation. Two decades have passed since the tragic conflict, but the issue of war crimes and criminals still has a negative influence on political relations between the Republic of Croatia and the Republic of Serbia. In the near future it will unquestionably be an obstacle for common initiatives and political cooperation.

\section{BIBLIOGRAPHY}

Akhavan, P. (2008). Reconciling crimes against humanity with the laws of war. Journal of International Criminal Justice, 6(1), 21-37. https://doi.org/10.1093/jicj/mqn001

Akrivoulis, D. E. (2017). Memory, forgiveness and unfinished justice in the former Yugoslavia. Journal of Balkan and Near Eastern Studies, 19(4), 366-387. https://doi.org/10.1 080/19448953.2017.1280978

Bieber, F. (2003). Approaches to political violence and terrorism in former Yugoslavia 1. Journal of Southern Europe and the Balkans, 5(1), 39-51. https://doi. org/10.1080/1461319032000062642

Bjelajac, M., \& Žunec, O. (n.d.). Rat u Hrvatskoj, 1991-1995. https://pescanik.net/wp-content/uploads/2016/04/rat-u-hrvatskoj-91-95.pdf

Burg, S., \& Shoup, P. (1999). The war in Bosnia-Herzegovina: Ethnic conflict and international intervention. M. E. Sharpe.

Butković, D. (2011, April 16). Samo 23\% Hrvata za ulazak u EU! Čak 95\% smatra presudu nepravednom. Jutarnji list. http://www.jutarnji.hr/vijesti/hrvatska/ekskluzivno-samo-23-hrvata-za-ulazak-u-eu-cak-95-smatra-presudu-nepravednom/2042394/

Croatian Mine Action Centre. (n.d.). https://misportal.hcr.hr/HCRweb/faces/simple/Map. jspx

Dokumentaciono informacioni centar Veritas. (2014). Žrtve akcije "Oluja" na srpskoj strani. http://www.veritas.org.rs/srpske-zrtve-rata-i-poraca-na-podrucju-hrvatske-i-bivse-rsk1990-1998-godine/zrtve-akcije-oluja-na-srpskoj-strani-2014/

Dokumentaciono informacioni centar Veritas. (2015, February 2). Večernji list, 11.02.2015., Braneći Zakon o ništetnosti, Jadranka Kosor besmisleno brani - ništa. http://www.veritas.org.rs/vecernji-list-11-02-2015-braneci-zakon-o-nistetnosti-jadranka-kosor-besmisleno-brani-nista/

Dörmann, K. (2003). War crimes under the Rome Statute of the International Criminal Court, with a special focus on the negotiations on the elements of crimes. Max Planck Yearbook of United Nations Law, 7, 343-403. 
Državno odvjetništvo Republike Hrvatske. (2014). Ažurirano izvješće u radu o predmetima ratnih zločina. http://www.dorh.hr/dorh2003

Državno odvjetništvo Republike Hrvatske. (2017). Procesuiranje ratnih zločina tijekom 2016. i u prvoj polovici 2017. godine. http://www.dorh.hr/DrzavnoOdvjetnistvoRepublikeHrvatskeProcesuiranje

Frulli, M. (2001). Are crimes against humanity more serious than war crimes? European Journal of International Law, 12(2), 332-346. https://doi.org/10.1093/ejil/12.2.329

Hathaway, O. A., Strauch, P. K., Walton, B. A., \& Weinberg, Z. A. Y. (2019). What is a war crime? The Yale Journal of International Law, 44(1), 54-113.

Hayden, R. M. (2011). What's reconciliation got to do with it? The International Criminal Tribunal for the former Yugoslavia (ICTY) as antiwar profiteer. Journal of Intervention and Statebuilding, 5(3), 313-330. https://doi.org/10.1080/17502977.2011.595597

Hebda, W. (2018). Serbsko-chorwackie stosunki polityczne na przełomie XX i XXI wieku. Aspra.

Hoare, M. A. (2003). Genocide in the former Yugoslavia: A critique of left revisionism's denial. Journal of Genocide Research, 5(4), 543-562. https://doi.org/10.1080/ 1462352032000149495

Human Rights Watch. (2003). Broken promises: Impediments to refugee return. https:// www.hrw.org/reports/2003/croatia0903/croatia0903full.pdf

International Criminal Tribunal for the former Yugoslavia. (n.d.-a). Ademi and Norac: Medak Pocket (IT-04-78) (Case information sheet). http://www.icty.org/x/cases/ademi/cis/ en/cis_ademi_norac.pdf

International Criminal Tribunal for the former Yugoslavia. (n.d.-b). Goran Hadžić (IT-04-75) (Case information sheet). http://www.icty.org/x/cases/hadzic/cis/en/cis_hadzic_en.pdf

International Criminal Tribunal for the former Yugoslavia. (n.d.-c). Gotovina and Markač: Operation storm (IT-06-90) (Case information sheet). http://www.icty.org/x/cases/ gotovina/cis/en/cis_gotovina_al_en.pdf

International Criminal Tribunal for the former Yugoslavia. (n.d.-d). Interactive map: Benkovac. http://www.icty.org/en/cases/interactive-map

International Criminal Tribunal for the former Yugoslavia. (n.d.-e). Interactive map: Dubrovnik. http://www.icty.org/en/cases/interactive-map

International Criminal Tribunal for the former Yugoslavia. (n.d.-f). Interactive map: Gospić. http://www.icty.org/en/cases/interactive-map

International Criminal Tribunal for the former Yugoslavia. (n.d.-g). Interactive map: Knin. http://www.icty.org/en/cases/interactive-map

International Criminal Tribunal for the former Yugoslavia. (n.d.-h). Interactive map: Škabrnja. http://www.icty.org/en/cases/interactive-map

International Criminal Tribunal for the former Yugoslavia. (n.d.-i). Interactive map: Zagreb. http://www.icty.org/en/cases/interactive-map

International Criminal Tribunal for the former Yugoslavia. (n.d.-j). Janko Bobetko: Medak Pocket (IT-02-62) (Case information sheet). http://www.icty.org/x/cases/bobetko/cis/ en/cis_bobetko_en.pdf

International Criminal Tribunal for the former Yugoslavia. (n.d.-k). Milan Babić: RSK (IT-03-

72) (Case information sheet). http://www.icty.org/x/cases/babic/cis/en/cis_babic_en.pdf International Criminal Tribunal for the former Yugoslavia. (n.d.-I). Milan Martić: RSK (IT95-11) (Case information sheet). http://www.icty.org/x/cases/martic/cis/en/cis_martic_ en.pdf 
International Criminal Tribunal for the former Yugoslavia. (n.d.-m). Miodrag Jokić: Dubrovnik (IT-01-42/1) (Case information sheet). http://www.icty.org/x/cases/miodrag_jokic/cis/en/cis_jokic_en.pdf

International Criminal Tribunal for the former Yugoslavia. (n.d.-n). Mrkšić et al.: Vukovar Hospital (IT-95-13/1) (Case information sheet). http://www.icty.org/x/cases/mrksic/cis/ en/cis_mrksic_al_en.pdf

International Criminal Tribunal for the former Yugoslavia. (n.d.-o). Radovan Karadžić (IT-955/18) (Case information sheet). http://www.icty.org/x/cases/karadzic/cis/en/cis_karadzic_ en.pdf

International Criminal Tribunal for the former Yugoslavia. (n.d.-p). Ratko Mladić (IT-09-92) (Case information sheet). http://www.icty.org/x/cases/mladic/cis/en/cis_mladic_en.pdf

International Criminal Tribunal for the former Yugoslavia. (n.d.-q). Slavko Dokmanović: Vukovar Hospital (IT-95-13a) (Case information sheet). http://www.icty.org/x/cases/dokmanovic/cis/en/cis_dokmanovic.pdf

International Criminal Tribunal for the former Yugoslavia. (n.d.-r). Slobodan Milošević: Kosovo, Croatia and Bosnia (IT-02-54) (Case information sheet). http://www.icty.org/x/cases/slobodan_milosevic/cis/en/cis_milosevic_slobodan_en.pdf

International Criminal Tribunal for the former Yugoslavia. (n.d.-s). Vojislav Šešelj (IT-03-67) (Case information sheet). http://www.icty.org/x/cases/seselj/cis/en/cis_seselj_en.pdf

International Criminal Tribunal for the former Yugoslavia. (n.d.-t). Željko Ražnatović "Arkan" (IT-97-27) (Case information sheet). http://www.icty.org/x/cases/zeljko_raznjatovic/cis/en/cis_arkan_en.pdf

International Criminal Tribunal for the former Yugoslavia. (2019). Key figures at the cases. http://www.icty.org/en/cases/key-figures-cases

International Tribunal for the Prosecution of Persons Responsible for Serious Violations of International Humanitarian Law Committed in the Territory of the Former Yugoslavia since 1991. (2009). Update statute of the International Criminal Tribunal for the former Yugoslavia. http://www.icty.org/x/file/Legal\%20Library/Statute/statute_sept09_en.pdf

Iwanek, T. (2015). Zbrodnia ludobójstwa i zbrodnie przeciwko ludzkości w prawie międzynarodowym. Wolters Kluwer.

Kerr, R. (2007). Peace through justice? The International Criminal Tribunal for the former Yugoslavia. Southeast European and Black Sea Studies, 7(3), 375-382. https://doi. org/10.1080/14683850701565973

Komitet za prikupljanje podataka o izvrešenim zločinima protiv čovečnosti i međunarodnog prava. (1998). Zločin genocida nad Srbima u Logoru Lora u Splitu u periodu 1991.-1997.

MacFarland, S., \& Hamer, K. (2016). Jak ludobójstwo zostało uznane za zbrodnię - dziedzictwo Rafała Lemkina. Civitas et Lex, 10(2), 69-85. https://doi.org/10.31648/cetl.2306

Maier-Katkin, D., Mears, D. P., \& Bernard, T. J. (2009). Towards a criminology of crimes against humanity. Theoretical Criminology, 13(2), 231-247. https://doi.org/10.1177/ 1362480609102880

Makino, U. (2001). Final solutions, crimes against mankind: On the genesis and criticism of the concept of genocide. Journal of Genocide Research, 3(1), 49-73. https://doi. org/10.1080/14623520120037707

Marchuk, I. (2014). The fundamental concept of crime in international criminal law: A comparative law analysis. Springer-Verlag. https://doi.org/10.1007/978-3-642-28246-1 
Milojevich, J. (2019). Justified grievances? A quantitative examination of case outcomes at the International Tribunal for the former Yugoslavia (ICTY). Journal of Balkan and Near Eastern Studies, 21(4), 403-426. https://doi.org/10.1080/19448953.2017.1421414

Mirkovic, D. (2000). The historical link between the Ustasha genocide and the Croato-Serb civil war: 1991-1995. Journal of Genocide Research, 2(3), 363-373. https:// doi.org/10.1080/713677614

National strategy for the prosecution of war crimes for the period 2016-2020. (2016). Ministarstvo pravde. https://www.mpravde.gov.rs/files/National\%20Strategy\%20 for $\% 20$ the \%20Prosecution \%20of\%20War\%20Crimes.pdf

Nikolic, I. (2015). Serbia, Bosnia mark "Day of the Disappeared". Balkan Insight. http:// www.balkaninsight.com/en/article/serbia-bosnia-mark-missing-persons-day-08-31-2015

Pavlaković, V. (2010). Croatia, the International Criminal Tribunal for the former Yugoslavia, and general Gotovina as a political symbol. Europe-Asia Studies, 62(10), 17071740. https://doi.org/10.1080/09668136.2010.522426

Peskin, V., \& Boduszyński, M. P. (2003). International justice and domestic politics: Post Tudjman Croatia and the International Criminal Tribunal for the former Yugoslavia. Europe-Asia Studies, 55(7), 1117-1142. https://doi.org/10.1080/0966813032000130710

Radio Television of Republika Srpska. (2011, January 22). Služen parastos srbima ubijenim u akciji Maslenica. http://www.rtrs.tv/vijesti/vijest.php?id=34468

Radoš, I. (2011). Operacjia "Oluja" i srbijanski dnevni tisak. Časopis za suvremenu povijest, 43(1), 293-327.

Rašović, R. (2016, March 2). Povukli film za zločin u Dvoru tereti HV. Večernji list. http:// www.vecernji.hr/hrvatska/povukli-film-15-minuta-masakr-u-dvoru-jer-za-zlocin-tereti-hrvatsku-vojsku-1065012

Steflja, I. (2010). Identity crisis in post-conflict societies: The ICTY's role in defensive nationalism among the Serbs. Global Change, Peace \& Security, 22(2), 231-248. https:// doi.org/10.1080/14781151003770853

Straus, S. (2001). Contested meanings and conflicting imperatives: A conceptual analysis of genocide. Journal of Genocide Research, 3(3), 349-375. https://doi. org/10.1080/14623520120097189

Subotić, J. (2014). Legitimacy, scope, and conflicting claims on the ICTY: In the aftermath of Gotovina, Haradinaj and Perišić. Journal of Human Rights, 13(2), 170-185. https:// doi.org/10.1080/14754835.2013.824290

Tanjug. (2016, April 19). Kolinda se žalila Ban Ki Munu: Šešelj oslobođen iako su svedoci bili zastrašivani i potkupljivani. Blic. http://www.blic.rs/vesti/politika/kolinda-se-zalila-ban-ki-munu-seselj-osloboden-iako-su-svedoci-bili-zastrasivani-i/f2dwqzt

Telegraf. (2016). Slobodan Milosevic poisoned himself: Florence Hartmann claims that former president of Serbia committed suicide. http://www.telegraf.rs/english/2159227-slobodan-milosevic-poisoned-himself-florence-hartmann-claims-that-former-president-of-serbia-committed-suicide

Ten years of war crimes prosecutions in Serbia: Contours of justice: Analysis of the prosecution of war crimes in Serbia 2004-2013 (V. Bogojević, Trans.). (2014). Humanitarian Law Center. http://www.hlc-rdc.org/wp-content/uploads/2014/10/Analiza_2004-2013_ eng.pdf

Tužilaštvo za ratne zločine. (n.d.-a). http://www.tuzilastvorz.org.rs/sr/predmeti/predmeti-

Tužilaštvo za ratne zločine. (n.d.-b). Lovas (Devetak Ljuban i drugi). http://www.tuzilastvorz.org.rs/sr/predmeti/lovas-devetak-ljuban-i-drugi 
Tužilaštvo za ratne zločine. (n.d.-c). Ovčara I: Vujović i ostali. http://www.tuzilastvorz.org. rs/sr/predmeti/predmeti-/ov\%C4\%8Dara-i-vujovi\% C4\%87-i-ostali

Zakon o ništetnosti određenih pravnih akata pravosudnih tijela bivše JNA, SFRJ i Republike Srbije. (2011). Narodne novine, 2011(124/11).

Zambelli, N. (2010). A journey westward: A poststructuralist analysis of Croatia's identity and the problem of cooperation with the International Criminal Tribunal for the former Yugoslavia. Europe-Asia Studies, 62(10), 1661-1682. https://doi.org/10.1080/09668136 .2010 .522424

Žunec, O. (1998). Rat u Hrvatskoj 1991.-1995. 2. dio: Od Sarajevskog primirja do zavrsnih operacija. Polemos, 1(2), 111-136. 